\title{
Input-output structures of the Australian construction industry
}

\author{
Chunlu Liu and Shimeng $\mathrm{He}$ \\ School of Architecture and Built Environment, Deakin University, Geelong, Australia
}

\begin{abstract}
The Australian construction industry continues to play an important role in the national economy. Analysis using input-output tables makes it possible to understand the role of the construction industry in Australia's economy and its relationships to other major industries over years. This study applies several economic indicators to investigate the construction industry's contributions to gross national product and gross national income, as well as its backward and forward linkage indicators, and its output and input multipliers. The paper also investigates the purchases of goods and services by the construction industry from other sectors and its sales to other industries over the analysis period. Findings from this research may help policymakers to better understand the economic linkages between the construction industry and other major industries, and the structural changes in its inputs and outputs in relation to these others.
\end{abstract}

Keywords: Backward indicators, forward indicators, input-output analysis, linkages, structural changes.

\section{Paper type: Viewpoint}

\section{Introduction}

Over the past several decades, input-output tables have drawn attention from researchers and received considerable interest in studies of the construction sector. An input-output (IO) model studies the quantitative relationships between the output levels of different sectors of one or more economies, as a vital tool for national economic accounting and planning (Raa, 2010). Based on IO tables, analysis of sectoral input and output trends provides additional understanding because it reveals the structures of economic activities (Altimiras-Martin, 2014). IO tables make it possible to recognise and evaluate the features of a proposed structure for relating economic activities to a particular element using structural analysis.

The literature has disclosed two main trends for construction industries in developed economies. First, for industrialised economies the importance of the construction industry tends to decline (Bon, 2000). Second, the material input from the manufacturing sector to the construction industry trends to decrease in the long term, but the input from the service sector shows a growth trend. Studies by Gundes (2011a) and Pietroforte and Gregori (2003) examined these findings by analysing a number of countries across several decades, and Pietroforte, Gregori and Falagario (2009) demonstrated the shift of sectoral inputs from manufacturing to the services sector in relation to the construction industry.

However, most researchers have focused on studying different countries' industrial inputs spanning long periods. To some extent, this is due to the low comparability of available data and the lack of reliable data. The research presented in this paper applies the recently published IO

Copyright: Construction Economics and Building 2016. (C) 2016 Chunlu Liu and Shimeng he. This is an Open Access article distributed under the terms of the Creative Commons Attribution 4.0 Unported (CC BY 4.0) License (https://creativecommons.org/licenses/by/4.0/), allowing third parties to copy and redistribute the material in any medium or format and to remix, transform, and build upon the material for any purpose, even commercially, provided the original work is properly cited and states its license.

Citation: Liu, C, and He, S. 2016. Input-output structures of the Australian construction industry, Construction Economics and Building, 16(2), 56-70. DOI: http://dx.doi.org/10.5130/AJCEB.v16i2.4819

Corresponding author: Chunlu Liu; Email - chunlu.liu@deakin.edu.au

Publisher: University of Technology Sydney (UTS) ePress 
tables from the World Input-Output Database (WIOD) at basic current prices and presented in millions of US dollars. The WIOD comprises IO tables for 40 countries spanning 1995 to 2011. The comparability of the data is thus increased. The current study's aim of using this time series data from the WIOD is to investigate the effects of the Australian construction sector on the national economy, and the input and output trends over this period.

This study investigates the sectoral linkages between the construction industry and the Australian national economy, and the structural changes in the construction industry, over the period 19952011. Using four economic indicators, namely gross national product (GNP), gross national income (GNI), proportion of national employment and GNP per person, this study analyses the importance of the construction industry to the economy. This is followed by application of the backward linkage indicators and output multipliers, and the forward linkage indicators and input multipliers, in order to analyse the pull and push effects on the Australian economy. This study reveals the annual construction sectoral input and output trends for the first time over a long period in Australia.

\section{Underpinning literature of input-output analysis for construction}

Input-output tables provide detailed information about supply from one sector to another and show the movement of products or goods for inter-sectoral trading and final users in an economy. One main use of IO tables is to address issues of structural change. As the tables show all interrelationships in an economy at a particular time, researchers can compare different periods in order to investigate sector performance and structural change (Chiang, Cheng and Tang 2006). A horizontal row of IO tables shows the output of a given sector, while a vertical column presents the input requirements of the sector. The data from IO tables provides evidence about the importance of construction and other sectors to the Australian economy through IO analysis.

The IO approach is widely applied to investigating the construction sector in national economies and has been adopted by many researchers (Bon, 2000; Pietroforte and Gregori, 2003; Liu and Song, 2005; Song and Liu, 2006). Using input-output analysis for investigation of the contribution of construction to the economy has been performed for many industrialised economies, such as the USA (Bon, 2000), Australia (Song and Liu, 2006), Germany (Fremdling and Staeglin, 2014), Singapore (Toh and Thangavelu, 2013), Japan (Chiang, Cheng and Tang, 2006), France and the Netherlands (Liu and Song, 2005). These findings have provided evidence that the inputs of the construction industry have not changed significantly over time or across economies. IO tables have also been applied to the study of the construction sectors in many developing economies, such as China (Wu and Zhang, 2005), Thailand (Kofoworola and Gheewala, 2008) and Turkey (Gundes, 2011b).

In most of these studies, researchers have analysed the construction industry and the national economy via backward linkage indicators and output multipliers, and forward linkage indicators and input multipliers. Bon (2000) analysed the indicators of backward linkage, where the degree of industrialisation of a sector was represented by the effect per unit of local currency change in the demand for the given industry on the output from the other sectors of the economy, while forward linkage represented the effect per unit of local currency change to the value added to construction on the input from other sectors. In particular, Song and Liu (2006) discussed the Australian construction sector linkages in the 1990s and emphasised that Australia did not have high values for either forward or backward linkage indicators, which means that the construction sector in the Australian economy had weak economic push and pull capabilities in the 1990s. Gundes (2011a) suggested that better understanding of the structural changes in a construction sector is useful in strategy formulation at both industrial and enterprise levels. Due to data 
limitations, that research across nine countries investigated only five sub-periods from 1968 to 1990, and did not consider the sectoral pull and push effects.

Some researchers have applied input-output analysis to the relationships between industry structure and the national economy. Skolka (1989) used input-output tables for studying the structural transformation of Austria's economy. Hu and McAleer (2004) applied input-output tables to the analysis of construction industry structure and inter-industry relationships, and the relationship of construction to national economic growth in China. Most investigators have focused more on the role of the sectoral changes in the national economy and less on analysing the input structure of the construction sector (Gundes, 2011b). Researchers such as Bon (2000) and Pietroforte and Gregori (2003) attempted to detail changes in the input structure of building materials for the US construction industry. A recent study by Gundes (2011a) investigated the input trends for the construction industry across nine countries utilising convergence and divergence analysis. Pietroforte, Gregori and Falagario (2009) discussed changes in the input structure of the US construction sector in detail.

\section{Research method}

There is close interaction among industries in one economy, as they produce products by consuming the goods or services from other industries as their intermediate inputs or sell products from their own industry outputs to other sectors (Leontief, 1966). IO tables provide a view of the relationships between differing industries for a given year. Table 1 illustrates the fundamental structure and basic symbols of a common type of input-output table. Each column under the heading 'Production sector' gives domestic trade flows for sectoral product processes in detail. The rows of the table present the allocations of one industry, because goods and services can be consumed by other sectors as intermediate products, or by householders and government as final products, and the allocations for each industry can be seen in a particular row in detail. There is an important rule for IO tables, which is that the total value added $(\mathrm{V})$ is equal to the value of the total final demand $(Y)$.

Table 1: Structure of an input-output table

\begin{tabular}{|c|c|c|c|c|c|c|c|c|c|}
\hline & \multicolumn{5}{|c|}{ Production sector } & \multirow{2}{*}{$\begin{array}{c}\text { Intermediate } \\
\text { output }\end{array}$} & \multirow{2}{*}{$\begin{array}{c}\text { Final } \\
\text { demand }\end{array}$} & \multirow{2}{*}{$\begin{array}{c}\text { Total } \\
\text { output }\end{array}$} \\
\hline & & 1 & $\ldots$ & j & $\ldots$ & $\mathrm{n}$ & & & \\
\hline \multirow{5}{*}{$\begin{array}{l}\text { Production } \\
\text { sector }\end{array}$} & 1 & & & & & & & & \\
\hline & $\ldots$ & & & & & & & & \\
\hline & $\mathrm{i}$ & & & $\mathrm{X}_{\mathrm{ij}}$ & & & $\overline{X_{i .}}$ & $\mathrm{Y}_{\mathrm{i}}$ & $\mathrm{X}_{\mathrm{i}}$ \\
\hline & $\ldots$ & & & & & & & & \\
\hline & $\mathrm{n}$ & & & & & & & & \\
\hline \multicolumn{2}{|c|}{ Intermediate input } & & & $\mathrm{X}_{\mathrm{j}}$ & & & & & \\
\hline \multicolumn{2}{|c|}{ Value added } & & & $\overline{V_{j}}$ & & & & $\mathrm{Y}=\mathrm{V}$ & \\
\hline \multicolumn{2}{|c|}{ Total input } & & & $\overline{X_{j}}$ & & & & & \\
\hline
\end{tabular}

\section{Sectoral pull and push effects on the national economy}

Matrix input coefficients are the essence of IO analysis (Gundes, 2011a). The input coefficient (also called the technical coefficient) is calculated by dividing the intermediate flow $\mathrm{x}_{\mathrm{ij}}$ from sector $i$ to sector $j$ by the total input $X_{j}$ for sector $j$, as shown in Equation (1): 


$$
\text { Input coefficient } \mathrm{a}_{\mathrm{ij}}=\mathrm{x}_{\mathrm{ij}} / \mathrm{X}_{\mathrm{i}}
$$

A larger value of $\mathrm{a}_{\mathrm{ij}}$ shows a higher level of dependence of sector $\mathrm{j}$ on sector $\mathrm{i}$ in producing goods or services.

Similarly, Equation (2) calculates the output coefficient (also called the allocation coefficient) by dividing $\mathrm{x}_{\mathrm{ij}}$ by the total of sector $\mathrm{i}, \mathrm{X}_{\mathrm{i}}$ :

$$
\text { Output coefficient } \mathrm{b}_{\mathrm{ij}}=\mathrm{x}_{\mathrm{ij}} / \mathrm{X}_{\mathrm{i}}
$$

The output coefficient represents the sales of sector $i$ to sector $j$ per monetary unit of the total output of sector $\mathrm{i}$.

Equation (3) calculates the backward linkage indicator by dividing the intermediate input of sector $\mathrm{j}$ by its total input (also called the input allocation). Equation (4) calculates the output allocation of sector $\mathrm{i}$ (also called the forward linkage indicator) by dividing the intermediate output of sector $\mathrm{i}$ by its total output:

$$
\begin{aligned}
& \text { Backward linkage indicator }=X_{. j} / X_{j} \\
& \text { Forward linkage indicator }=X_{\mathrm{i}} / \mathrm{X}_{\mathrm{i}}
\end{aligned}
$$

Equations (5) and (6) calculate the output and input multipliers respectively. $(\mathrm{I}-\mathrm{A})^{-1}$ and $(\mathrm{I}-\mathrm{B})^{-1}$ are the Leontief and Ghosh inverse matrixes respectively, in which $\mathrm{I}$ is an identity matrix, while $\mathrm{A}$ and $\mathrm{B}$ denote the input and output coefficient matrixes respectively:

$$
\begin{aligned}
& \text { Output multiplier }=\sum_{i=1}^{n}(\mathrm{I}-\mathrm{A})^{-1} \\
& \text { Input multiplier }=\sum_{j=1}^{n}(\mathrm{I}-\mathrm{B})^{-1}
\end{aligned}
$$

An element in the Leontief inverse matrix, $1_{i j}$ (also called the total-input coefficient), represents the effect of change of one monetary unit in the final demand of sector $j$ on the total output of sector i. The column sum of the total-input coefficients for sector $j$, expressed in Equation (5) and also called the demand multiplier or total-backward linkage indicator, adds up the effect of sector $j$ on the total output of all sectors.

Similarly, an element in the Ghosh inverse matrix, $g_{i j}$ (also called the total-output coefficient), represents the effect of change of one monetary unit in the value added by sector $i$ on the total input of sector $j$. The row sum of the total-output coefficients for sector $i$, expressed in Equation (6) and also called the total-forward linkage indicator, adds up the effect of sector $i$ on the total input of all sectors.

\section{Sectoral indicators in the national economy}

For comparison, differing economic indicators for the construction industry in relation to the national economy are defined. GNP represents domestic production. The proportion of construction in GNP is calculated in Equation (7) by dividing the final demand of the construction sector $\left(\mathrm{Y}_{\mathrm{i}}\right)$ by final demand $(\mathrm{Y})$ :

$$
\text { Proportion of construction in GNP }=\mathrm{Y}_{\mathrm{i}} / \mathrm{Y}
$$

A larger value of the proportion of construction in GNP shows a higher level of dependence of the national economy on the construction industry.

Similarly, the proportion of construction in GNI is calculated in Equation (8) by dividing the value added by the construction sector $\left(\mathrm{V}_{j}\right)$ by the total value added $(\mathrm{V})$ :

$$
\text { Proportion of construction in } \mathrm{GNI}=\mathrm{V}_{\mathrm{j}} / \mathrm{V}
$$


The construction value added (CVA) per person is calculated in Equation (9) by dividing $\mathrm{V}_{\mathrm{j}}$ by the amount of construction employment, and the construction GNP per person is calculated in Equation (10) by dividing $\mathrm{Y}_{\mathrm{i}}$ by the amount of construction employment:

$$
\begin{aligned}
& \text { Construction value added }(\mathrm{CVA})=\mathrm{V}_{\mathrm{j}} / \text { construction employment } \\
& \text { Construction GNP per person }=\mathrm{Y}_{\mathrm{i}} / \text { construction employment }
\end{aligned}
$$

The proportion of domestic labour engaged in construction is another important economic indicator. It denotes the share of construction in national employment and is calculated by dividing construction employment by national employment.

\section{The world input-output database}

In this study, the IO table for the years 1995-2011 is taken from the World Input-Output Database (Timmer et al., 2015). The WIOD project operated from May 2009 to April 2012 with 11 countries. It provides a tool for both government policymakers for their requirements and professional and academic researchers for testing and study. The WIOD provides information about national production and international trade. There are 40 countries in the latest database, including 27 countries from the European Union, for the time period from 1995 to 2011 (Diezenbacher at el., 2013). The WIOD combines economic activities and trade information at basic current prices.

The data for the WIOD tables is collected from systems of national accounts, national inputoutput tables and international trade reports, which are released by government statistics agencies of each country, and the data is presented in millions of US dollars. There is an additional table providing the exchange rates used to convert local currencies into US dollars for each year. This dataset provides a harmonised 35-industry structure (see Appendix 1). The tables have been compiled based on official trade statistics, providing an integrated image of the structure of these national economies. The data for construction labour engaged for a given period is taken from the WIOD as well. This data covers economic indications of construction value added (CVA) per person and construction GNP per person.

\section{The Australian construction sector}

Calculating the proportions of construction to GNP, GNI, domestic labour engaged, CVA per person and GNP per person provides evidence of the relationships of construction within a particular economy over a given period. Higher values of these economic indicators show larger contributions from the construction sector to the economy over a certain period. All these economic indicators are shown in Table 2.

The time period contains five stages, 1995-97, 1997-99, 1999-2000, 2000-07 and 2007-11. In the first stage, the shares of GNP and GNI decreased from $16.49 \%$ and $7.15 \%$ to $14.33 \%$ and $6.76 \%$ respectively, while CVA per person increased from $\$ 47.42$ to $\$ 52.98$. In the second stage, the share of GNI increased slightly from $6.76 \%$ to $7.17 \%$ whereas the shares of GNP and GNP per person decreased. In the third stage, all data decreased. In stage four, the shares of GNP, GNI, domestic labour engaged by construction, CVA per person and GNP per person all increased, from $10.64 \%, 5.86 \%, 7.43 \%, \$ 50.64$ and $\$ 117.08$ to $14.47 \%, 8.03 \%, 9.18 \%, \$ 79.14$ and $\$ 181.86$ respectively. The shares in GNI and national employment from stages one to four experienced a W-shape, that is, they decreased in the first and third stages, but grew in the second and fourth stages. In the last stage, economic growth slowed and all shares either decreased or increased only slightly.

There is an upward trend for all shares over the period 2000-11. Additionally, there is significant evidence of growth trends for not only CVA but also GNP per person over the whole study 
period. Therefore, it can be concluded that the Australian construction sector experienced significant growth until the 2007 economic slowdown. This goes against Bon's (2000) argument that advanced industrial countries tend to experience both an absolute drop and a relative drop in construction volume. Over the period from 1995 to 2011, Australia experienced a rough Vshape in its construction industry, with the economic indicators decreasing until 2000 and then all indicators experiencing increasing trends until 2011.

Table 2: The economic indicators for the Australian construction industry

\begin{tabular}{|c|c|c|c|c|c|}
\hline Year & $\begin{array}{c}\text { Proportion } \\
\text { in GNP (\%) }\end{array}$ & $\begin{array}{c}\text { Proportion } \\
\text { in GNI (\%) }\end{array}$ & $\begin{array}{c}\text { Proportion in } \\
\text { national employment } \\
\mathbf{( \% )}\end{array}$ & $\begin{array}{c}\text { CVA per } \\
\text { person } \\
\mathbf{( \$ 1 0 0 0 )}\end{array}$ & $\begin{array}{c}\text { CNP per } \\
\text { person } \\
\mathbf{( \$ 1 0 0 0 )}\end{array}$ \\
\hline 1995 & 16.49 & 7.15 & 7.24 & 47.42 & 153.00 \\
\hline 1996 & 16.25 & 7.11 & 7.01 & 51.47 & 162.30 \\
\hline 1997 & 14.33 & 6.76 & 7.05 & 52.98 & 151.36 \\
\hline 1998 & 14.03 & 6.99 & 7.31 & 55.20 & 144.24 \\
\hline 1999 & 13.41 & 7.17 & 7.78 & 57.05 & 134.99 \\
\hline 2000 & 10.64 & 5.86 & 7.43 & 50.64 & 117.07 \\
\hline 2001 & 11.20 & 6.31 & 7.60 & 57.19 & 125.99 \\
\hline 2002 & 12.24 & 6.78 & 7.67 & 61.97 & 140.85 \\
\hline 2003 & 12.91 & 7.31 & 8.15 & 66.90 & 146.42 \\
\hline 2004 & 13.41 & 7.54 & 8.54 & 68.14 & 152.37 \\
\hline 2005 & 16.67 & 7.62 & 8.73 & 70.41 & 160.41 \\
\hline 2006 & 14.22 & 7.94 & 9.11 & 75.16 & 169.42 \\
\hline 2007 & 14.47 & 8.03 & 9.18 & 79.14 & 181.86 \\
\hline 2008 & 14.19 & 8.10 & 9.40 & 82.93 & 183.85 \\
\hline 2009 & 14.28 & 8.15 & 9.32 & 88.41 & 193.24 \\
\hline 2010 & 13.63 & 7.79 & 9.28 & 90.50 & 196.78 \\
\hline 2011 & 13.96 & 7.92 & 9.26 & 93.23 & 207.84 \\
\hline
\end{tabular}

All of the above economic indicators suggest that the Australian construction industry experienced significant decline in the late 1990s. This may be related to the Asian financial crisis of 1997-98 and/or the introduction of the goods and services tax (GST) in Australia from 2000. It was a considerable rate of growth that the Australian construction industry experienced during 2000 to 2011. One possible reason for this is that housing investment strongly rebounded and there was a boost in residential construction. Low interest rates and improving household wealth also strengthened both residential and non-residential building construction.

Research has shown that the proportion of construction employment in advanced industrial countries tends to drop, because local construction firms focus on providing constructionrelated services and project management, and so demand for direct labour decreases in these countries (Bon, 2000). The lower the construction technology that is applied in a construction project, the higher the direct labour force demand is in compensation. As shown in Figure 1, national employment and construction employment over 1995-2011 both increased significantly in Australia, in particular in the 2000s. This implies that Australian construction technology may have fallen behind that of other advanced industrial countries. 


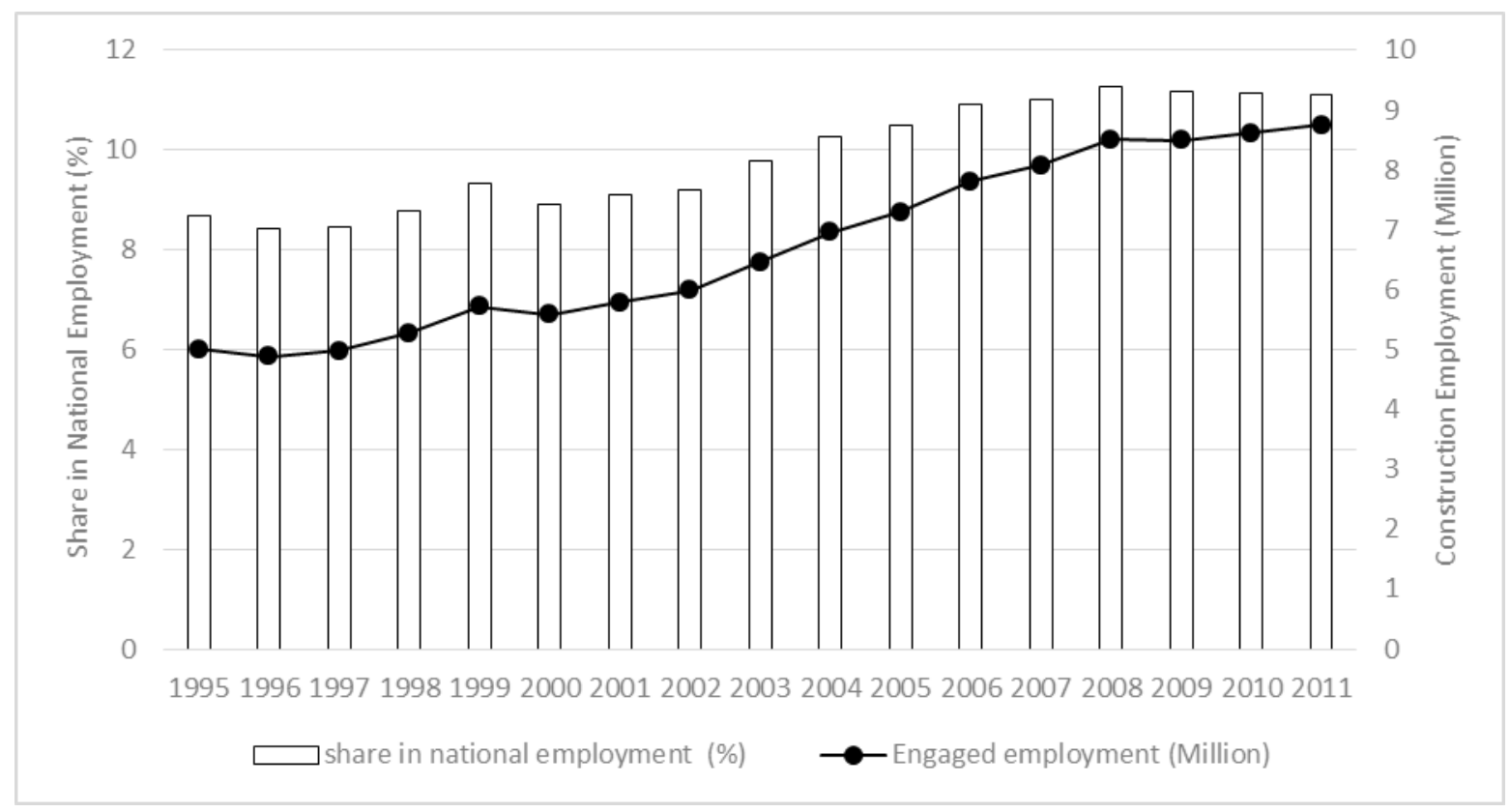

Figure 1: Annual domestic labour engaged by the construction sector and proportion of the construction sector in national employment

\section{Pull effects and input structure of the Australian construction industry}

\section{Backward linkages and pull effects}

A backward linkage indicator represents the proportion of the inputs into a sector from other sectors in a particular economy, inputs such as capital, land and labour. This indicator is the rate of the intermediate input to the total input for a particular sector. It also reveals the levels of both technology and industrialisation in a given industry in an economy during manufacturing of the sectoral products, including the industrial components and the offsite work on the construction materials. In particular, the backward linkage indicator shows the level of strength of the pull effect from the national construction industry on the national economy. Accordingly, a larger backward linkage indicator denotes that the pull effect from the construction industry on the economy is stronger and that the level of technology of the inputs from other industries is higher.

Figure 2 shows the sectoral pull effect on the national economy in Australia from the construction industry over 1995 to 2011 . The backward linkage indicators were stable, with values between 0.51 and 0.70 . The average value of the backward linkage indicators for the construction industry in the late 1990s was 0.66 and it tended to stabilise around 0.68 in the 2000s. On the other hand, both the levels of the industrialisation of construction and the modern technology applying to construction projects were not very high. Figure 2 reveals that the backward linkage indicators from construction were much higher than the averages of other industries. The average values of the other industrial backward linkage indicators were between 0.3 and 0.5 . It can be concluded that the construction industry provided one of the strongest sectoral pull effects on the Australian economy over the years 1995 to 2011. The values of the backward linkage indicators for the construction industry being higher than 0.5 , indicates that most of the materials and prefabrication for construction, were produced by off-site work.

Figure 3 presents the output multipliers of the Australian construction industry from 1995 to 2011. An output multiplier represents the total effect per monetary unit change in the final demand of the Australian construction industry on the total output of all industries, including 
goods and services. The average output multiplier indicators of all sectors were around 1.83 to 1.90 , and the sectoral indicators from the construction industry generally had higher values than average. This shows that the construction industry purchased larger numbers of products from different industries when producing sectoral goods and services.

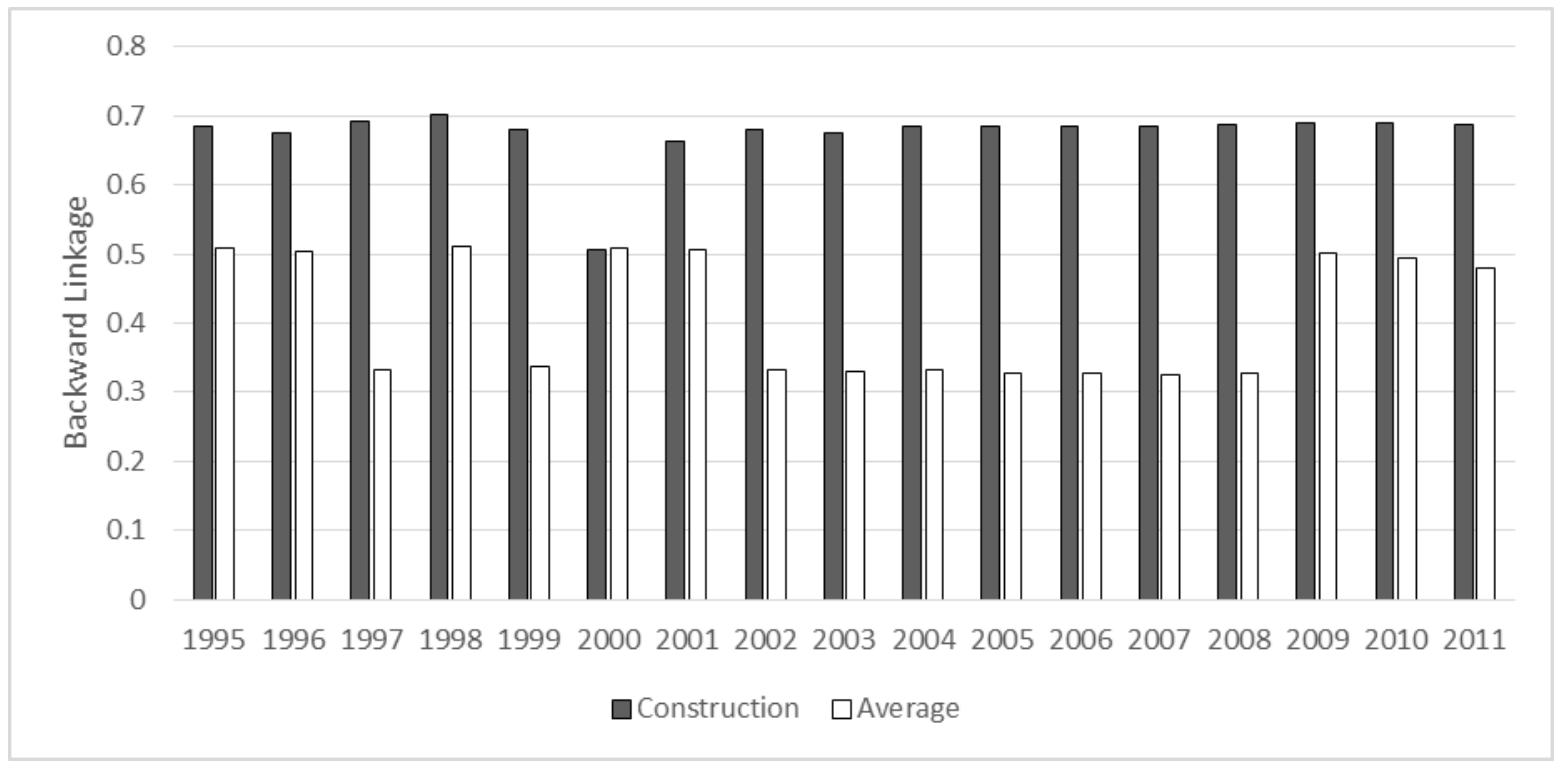

Figure 2: Average and construction backward linkage indicators

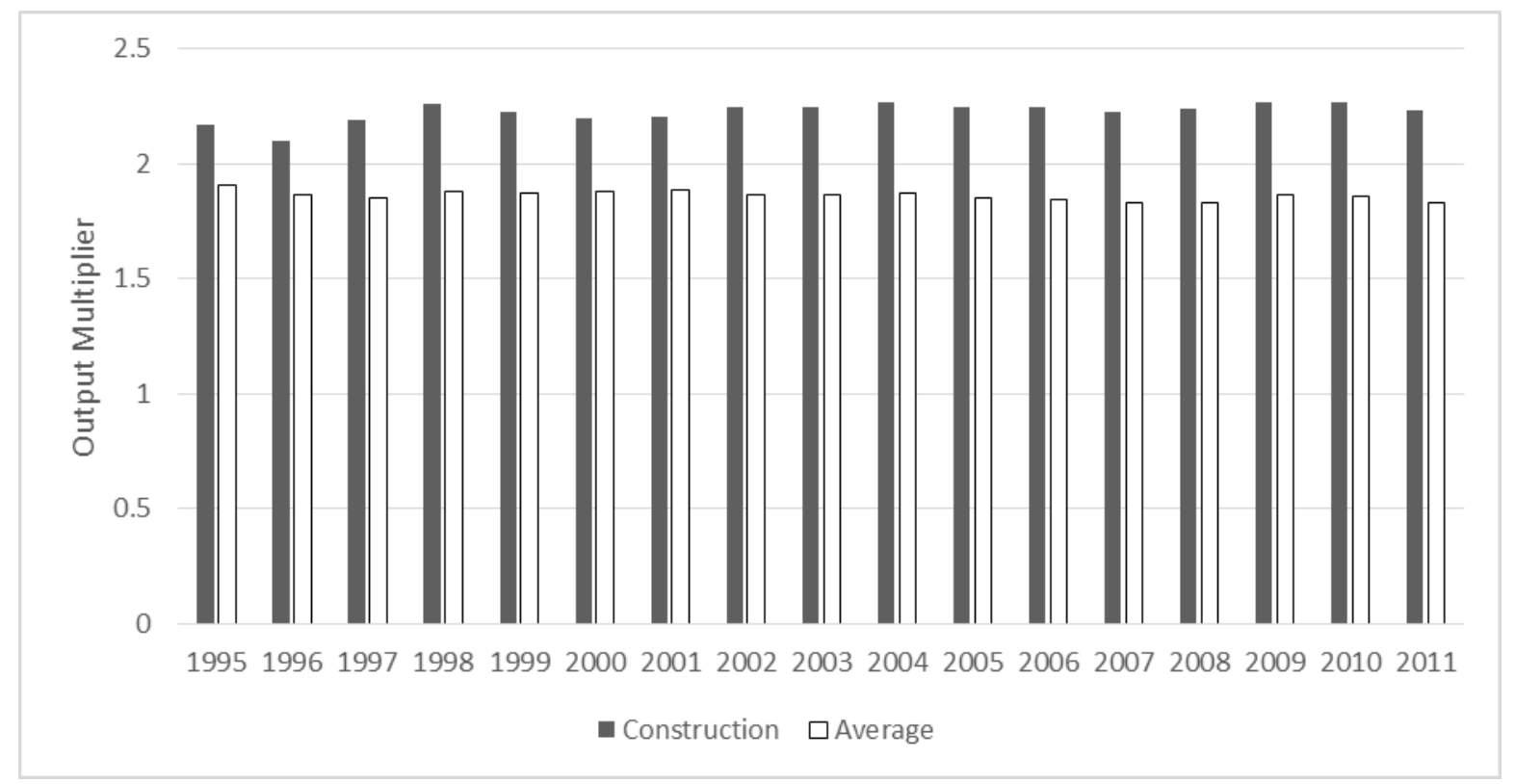

Figure 3: Average and construction output multipliers

\section{Input trend for the construction industry}

Table 3 ranks the top 10 industries from which the construction industry purchased its inputs in each year from 1995 to 2011. These top 10 industries are: Construction (18); Renting of M\&Eq and Other Business Activities (30); Basic Metals and Fabricated Metals (12); Other Non-Metallic Minerals (11); Financial Intermediation (28); Real Estate Activities (29); Wood and Products of Wood and Cork (6); Wholesale Trade and Commission Trade, Except of Motor Vehicles and Motorcycles (20); Retail Trade, Except of Motor Vehicles and Motorcycles; Repair of Household Goods (21); and Sale, Maintenance and Repair of Motor Vehicles and Motorcycles; Retail Sale of Fuel (19). 
Table 3: Ranks of top 10 sectors from which the construction industry purchased its inputs

\begin{tabular}{|c|c|}
\hline Year & Ranks of sectors from top 1 to 10 \\
\hline 1995 & $12,11,30,29,20,21,6,23,19,28$ \\
\hline 1996 & $12,11,30,29,20,21,6,23,19,28$ \\
\hline 1997 & $18,12,30,11,29,20,21,6,28,19$ \\
\hline 1998 & $18,30,11,12,29,20,28,21,6,19$ \\
\hline 1999 & $18,30,11,12,29,28,20,6,21,19$ \\
\hline 2000 & $18,30,11,12,29,28,6,20,21,19$ \\
\hline 2001 & $18,30,11,12,28,29,6,20,21,19$ \\
\hline 2002 & $18,30,12,11,28,29,6,20,21,17$ \\
\hline 2003 & $18,30,11,12,28,29,6,21,20,27$ \\
\hline 2004 & $18,30,12,11,28,29,6,21,20,19$ \\
\hline 2005 & $18,30,12,11,28,29,6,21,20,19$ \\
\hline 2006 & $18,30,12,28,11,29,6,21,20,19$ \\
\hline 2007 & $18,30,12,28,11,29,6,21,20,19$ \\
\hline 2008 & $18,30,28,12,11,29,6,21,20,19$ \\
\hline 2009 & $18,30,12,28,11,29,6,21,20,19$ \\
\hline 2010 & $18,30,12,28,11,29,6,21,20,2$ \\
\hline 2011 & $18,30,12,28,29,11,6,21,20,2$ \\
\hline Overall & $18,30,12,11,28,29,6,21,20,19$ \\
\hline
\end{tabular}

As can be seen from this table, Basic Metals and Fabricated Metals (12), Other Non-Metallic Minerals (11) and Renting of M\&Eq and Other Business Activities (30) always had high coefficient values over the subject period; two of these belong to the manufacturing sector. Renting of M\&Eq and Other Business Activities (30) was the third highest technical coefficient input in 1995-1997 and then replaced Basic Metals and Fabricated Metals (12) to take second place following Construction (18) until 2011.

Construction includes construction management, administration and engineering services, all of them requiring the construction industry in order to provide their professional services. This reflects both the increasing number of domestic construction projects and the market demand for professional construction practitioners. The increasing number of subcontractors may be the result of many of the direct contractors for large site construction projects moving towards the use of professional subcontractors; this is also called outsourcing. Outsourcing has a number of advantages, including that it significantly reduces the responsibilities of direct general contractors and improves the efficiency of labour management in complex construction projects.

Basic Metals and Fabricated Metals (12) are the metals for building materials and construction components. From the discussion of Bon, Birgonul and Ozdogan (1999), the increasing trend for this sector may reflect the large amount of off-site work of the construction sector. The significant increase in Basic Metals and Fabricated Metals may also be explained by the growth trend in offshore work.

Other Non-Metallic Minerals (11) are the non-metal minerals used for a wide range of construction materials and prefabrication manufacturing. They include silicon, cement, calcium carbonate, ceramics and glass. Over the whole period from 1995 to 2011, Other Non-Metallic Minerals (11) was one of the essential inputs to the construction sector. There was a slowly decreasing trend for this sector. It was the second highest input to the construction industry in the 1990s, but became the fifth in the late 2000s. The most likely reason for this change is the development of construction technology, because most of these products such as glass, cement and calcium carbonate were more widely used in traditional building technology. This change may reflect the Australian construction industry transforming from the traditional model to the 
modern model. Glass is one of the favoured materials in modern construction and there are no substitute products for glass. Its use may increase in future, but that of other non-metal minerals may decrease slowly to a certain point and then stabilise until substitute products become available.

The input from Financial Intermediation (28) to the construction industry continually increased over the whole period 1995-2011. The most considerable growth was in 1996-99, although the economic environment for the construction sector was not favourable then, and this sector climbed to become the fifth and sixth highest technical coefficient. The financial chain is important for every construction project and financial intermediation is the market practitioner providing the funds for construction projects. The rapid growth of this sector may enhance the availability of credit for construction projects from national and global financial institutions such as banks. This improves the financing opportunities of the construction sector for construction projects.

The input coefficient from Real Estate Activities (29) is the value reflecting real estate market activities including buying, selling and leasing of properties. Over the years 1995 to 2010, its input coefficients decreased considerably. The introduction of the GST in Australia had a profound impact on the significantly increasing prices of construction materials, which is a crucial reason for this decreasing value of the input coefficients. In 2011, its technical coefficient to construction moved up one step to fifth place after 10 years of being sixth.

In contrast to the above, over the whole period from 1995 to 2011, the input coefficients from Wood and Products of Wood and Cork (6) to the construction industry were almost unchanging. The sector remained in seventh highest place except in 1997-99. This may be attributable to the building styles of Australian houses, most of which are constructed from wooden frames.

Sector 20 provides a picture of how construction products are allocated and distributed in relation to the national economy. From 1995 to 2003, it decreased gradually from being the fifth highest input to construction to becoming the ninth, and then remained unchanged to 2011. The technical coefficient of this sector did not increase because of the diversity of national construction projects and wide geographic dispersion found in Australia. In addition, the technical coefficients of sector 21 to the construction industry presented a U-sharp curve over the subject period. From 1995 to 1999, the values of this input coefficient gradually dropped from sixth place to ninth place and then steadied by 2002. Its position rose to eighth in 2003 and remained there to the end of the study period.

Inland Transport (23) lost ground in technology input to the construction industry after 1997. Its technical coefficient was in the top 10 industries only in the first two years. From the years 1997 to 2001 and 2004 to 2009, sector 19 took ninth place in the top 10 highest inputs to the construction industry. However, this sector also decreased in the other years. Electricity, Gas and Water Supply (17) and Post and Telecommunications (27) appeared in the top 10 highest inputs to the construction industry in 2002 and 2003 respectively. The growing trend of Mining and Quarrying (2) emerged from 2010 onwards. This sector is directly related to road and basic infrastructure construction projects.

\section{Forward linkages and output structure of the Australian construction industry}

\section{Forward linkages and push effects}

Figure 4 shows the forward linkage indicators and input multipliers of the construction industry relative to the national economy from 1995 to 2011. Forward linkage indicators represent the output of construction to the other sectors of an economy. Higher values of the forward 
indicators mean a stronger push effect on the national economy from the construction sector. The input multiplier is the value representing the effect per monetary unit change in value added by the construction industry on the total input of all other industries in an economy.

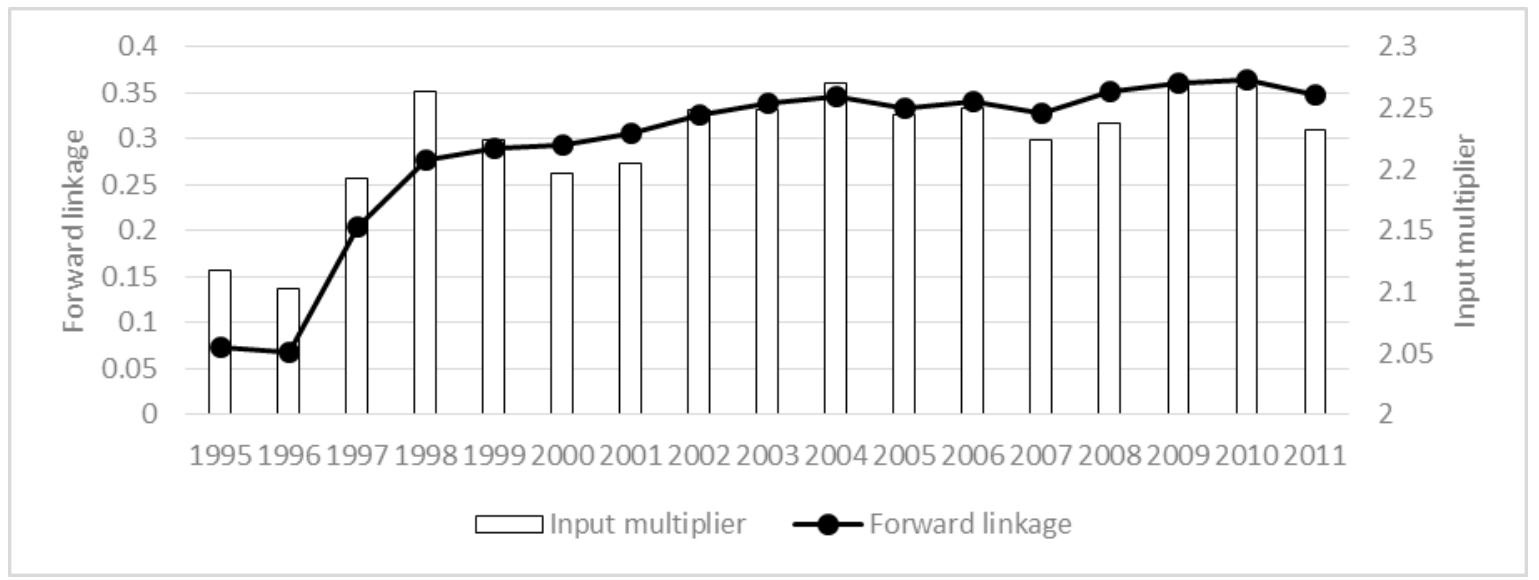

Figure 4: Input multipliers and forward linkage indicators of the Australian construction industry

For the first two years of the study period, the forward linkage indicators were 0.07 and 0.06 , which shows a very weak push effect on the economy. Then there was a big jump from 1997 onwards, when the forward indicator values rapidly grew to 0.20 . This was probably due to the large construction investment for the 2000 Sydney Olympic Games and the introduction of the GST, which caused significant increases in the prices of construction materials in the late 1990s. Over the following years, the forward linkage indicators continually increased to about 0.35 in the 2000s.

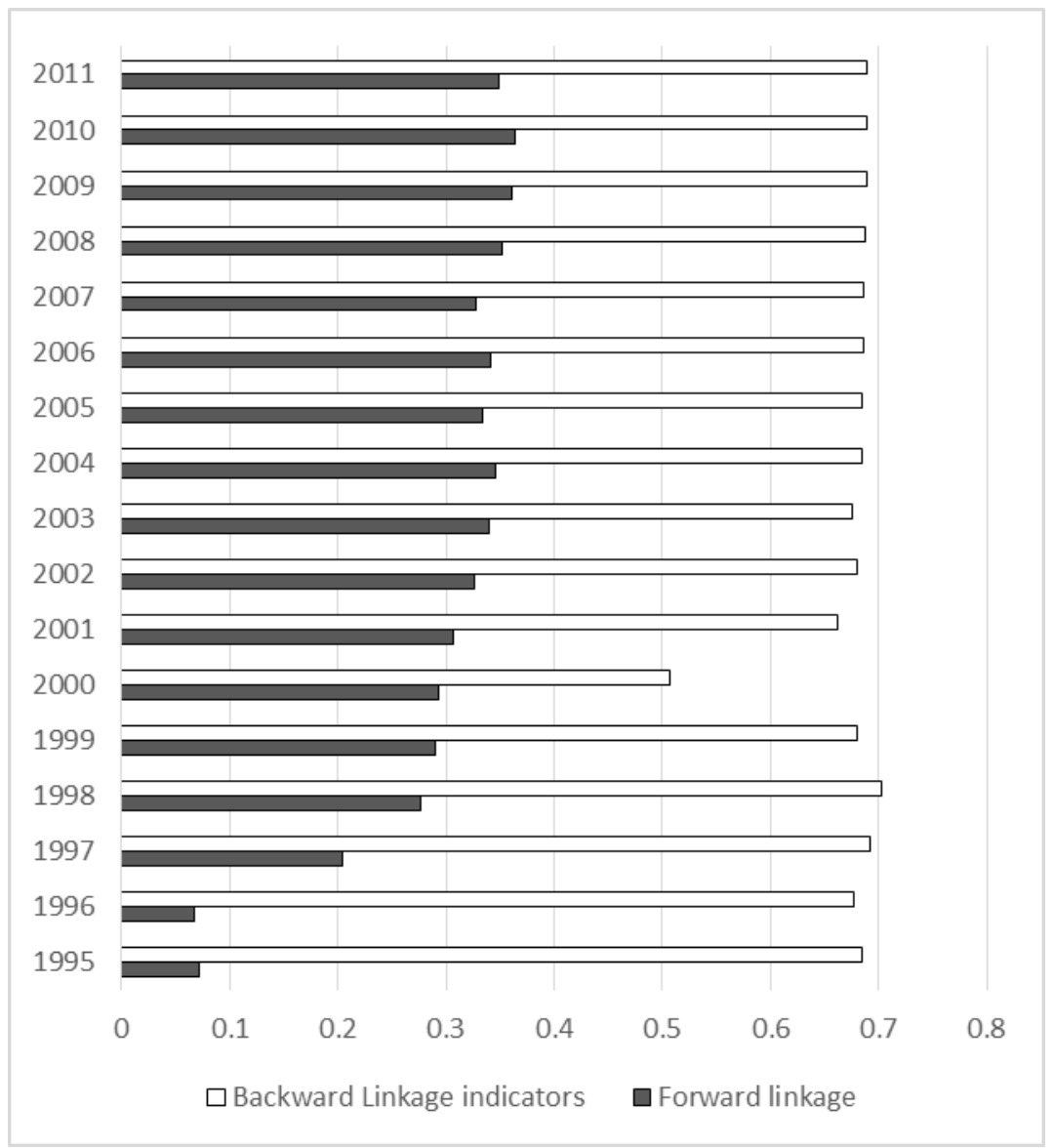

Figure 5: Comparison of backward and forward linkages of construction in Australia 
In comparison of the backward and forward linkage indicators for the Australian construction industry, as shown in Figure 5, it can be observed that the backward linkage values were much larger than the forward linkage values in all years, showing that the pull capabilities of the construction industry were larger than its push capabilities. This was likely due to the nature of construction, which needs large amounts of goods and services from other industries.

\section{Output trend of the construction industry}

Table 4 presents the top 10 industries to which the construction sector sold its outputs in each year from 1995 to 2011. It is worth noting that some of these industries had stable values while others were very variable. There is an essential output from the construction industry to Mining and Quarrying (2). Its output coefficients showed a U-shape over the whole period. In the late 1990 s and early 2000s, the output coefficients of construction to Mining and Quarrying decreased and then there was a general upward trend until 2011. Due to global market demand there was a boom in the national mining industry for large amounts of goods and services consumption from the construction sector.

Table 4: Ranks of top 10 sectors to which the construction industry sold its outputs

\begin{tabular}{|c|c|}
\hline Year & Ranks of sectors from top 1 to 10 \\
\hline 1995 & $29,31,22,1,2,23,20,18,26,30$ \\
\hline 1996 & $29,31,22,2,1,23,20,18,26,30$ \\
\hline 1997 & $18,29,31,2,27,17,22,1,20,23$ \\
\hline 1998 & $18,29,31,2,17,27,30,22,20,10$ \\
\hline 1999 & $18,29,31,27,17,2,30,21,22,20$ \\
\hline 2000 & $18,31,29,2,17,27,21,30,23,22$ \\
\hline 2001 & $18,31,29,17,2,27,21,30,23,22$ \\
\hline 2002 & $18,31,29,17,2,27,30,21,23,22$ \\
\hline 2003 & $18,31,29,17,2,27,30,23,21,22$ \\
\hline 2004 & $18,31,29,2,17,27,23,30,22,21$ \\
\hline 2005 & $18,31,2,29,17,27,23,30,22,21$ \\
\hline 2006 & $18,31,2,29,17,27,30,23,22,21$ \\
\hline 2007 & $18,31,2,29,17,27,30,23,21,22$ \\
\hline 2008 & $18,2,31,29,17,27,30,21,23,22$ \\
\hline 2009 & $18,2,31,29,17,27,30,23,21,22$ \\
\hline 2010 & $18,2,31,29,17,27,30,23,21,22$ \\
\hline 2011 & $18,2,31,29,17,30,27,23,21,22$ \\
\hline Overall & $18,2,31,29,17,27,30,23,21,22$ \\
\hline
\end{tabular}

Public Admin and Defence; Compulsory Social Security (31) includes government activities. The growing trend for this sector reflects the increasing amount of national government administration investment over the subject period. The significantly high values for the output coefficient of construction to this sector may result from the growth of taxation as well. After the GST was introduced in 2000, the output coefficient for this sector became the highest except for Construction from 2000 to 2007.

Real Estate Activities (29) are related to the market activities of property such as buying, selling and leasing property or land. This sector was always one of the most essential outputs from construction, but there was a considerable decline over the whole study period. Its output coefficient decreased gradually from first position in 1995 and 1996 to fourth from 2005 onwards. 
The values for the sectors Electricity, Gas and Water Supply (17), Post and Telecommunications (27) and Inland Transport (23) show the product demand from these national service sectors towards the construction industry. There was a slight but increasing trend in this group. The output coefficient values of the construction industry in sectors 17 and 27 first appeared in the top 10 in 1997 and they were both stable in the ranking table over the study period.

The output coefficient values to Inland Transport (23) were variable over the whole period. Its output coefficient experienced a striking recession in the late 1990s. Over 1995-96, the value of its output coefficient took sixth place, was ranked tenth in 1997 and disappeared from the table in 1998 and 1999. Over the 2000s, the output coefficients of this sector experienced considerable improvement at the beginning and had stable values in the remaining years.

Renting of M\&Eq and Other Business Activities (30) had the weakest output coefficient values of the construction industry over 1995-96 and disappeared in 1997. It became the seventh largest output in 1998. Over 1998-2010, the values of sector 30 were stable and they increased in 2011.

Retail Trade, Except of Motor Vehicles and Motorcycles; Repair of Household Goods (21) was not one of the top 10 outputs of the construction industry before 1999. It took eighth place in 1999 and moved to seventh in 2000 and 2001. Over 2002-11, the sectoral output coefficients experienced slight decline and rebounded.

Hotels and Restaurants (22) was ranked as the third industry with higher outputs from construction in the first two years. However, there was an acute decrease to seventh in 1997 and further declines in the following two years. From 2000 to 2011, its output coefficient was the tenth highest output of the construction industry except over 2005-06 when it was ninth.

There was considerable output from the construction sector to Wholesale Trade and Commission Trade, Except of Motor Vehicles and Motorcycles (20) from 1995 to 1999, but afterwards this sector lost ground and was no longer ranked in the top 10 industries.

\section{Conclusion}

This research has investigated the changes in input and output structures of the Australian construction industry relative to the national economy over the period 1995 to 2011. The study has applied economic indicators, including the proportions of GNI, GNP, sectoral employment and national employment, to analysis of the importance of the construction industry to the national economy. In particular, the proportion of GNP experienced a decline in the late 1990s, likely due to the introduction of the GST, but then increased considerably. Furthermore, the share of construction in national employment increased significantly in all the years of the study period.

The linkages between the construction industry and the other sectors from 1995 to 2011 indicate that the economic push and pull capabilities of the Australian construction industry both experienced growth trends. In general, the inputs and outputs of the construction industry remained very stable over the study period. In particular, the input from Other Non-Metallic Minerals (11) to construction decreased considerably over the whole period, while the input from Renting of M\&Eq and Other Business Activities (30) stabilised at a high level. The three highest output sectors from construction were Mining and Quarrying (2), Real Estate Activities (29) and Public Admin and Defence; Compulsory Social Security (31).

This comprehensive analysis of the input and output structures of the construction industry will enable both researchers and policymakers to better understand the economic linkages of the construction industry with other major industries and also the effects of changes within construction on the national economy of Australia. 


\section{References}

Altimiras-Martin, A., 2014. Analysing the structure of the economy using physical input-output tables. Economic Systems Research, 26(4), pp.463-85. doi: http://dx.doi.org/10.1080/09535314.2014.950637

Bon, R., 2000. Economic structure and maturity: collected papers in input-output modelling and applications. Michigan: Ashgate.

Bon, R., Birgonul, T. and Ozdogan, I., 1999. An input-output analysis of the Turkish construction sector, 19731990: a note. Construction Management \& Economics, 17(5), pp.543-51. doi: http://dx.doi.org/10.1080/014461999371169

Chiang, Y., Cheng, E. and Tang, B., 2006. Examining repercussions of consumptions and inputs placed on the construction sector by use of I-O tables and DEA. Building and Environment, 41(1), pp.1-11. doi: http://dx.doi.org/10.1016/j.buildenv.2005.01.006

Diezenbacher, E., Los, B., Stehrer, R., Timmer, M. and de Vries, G., 2013. The construction of World InputOutput Tables in the WIOD Project. Economic Systems Research, 25(1), pp.71-98. doi: http://dx.doi.org/10.1080/09535314.2012.761180

Fremdling, R. and Staeglin, R., 2014. An input-output table for Germany in 1936: a documentation of results, sources and research strategy. Economic History Yearbook, 55(2), pp.187-298. doi: http://dx.doi.org/10.1515/jbwg-2014-0018

Gundes, S., 2011a. Input structure of the construction industry: a cross-country analysis, 1968-90. Construction Management \& Economics, 29(6), pp.613-21. doi: http://dx.doi.org/10.1080/01446193.2011.563787

Gundes, S., 2011b. Exploring the dynamics of the Turkish construction industry using input-output analysis. Construction Management \& Economics, 29(1), pp.59-68. doi: http://dx.doi.org/10.1080/01446193.2010.529925

$\mathrm{Hu}, \mathrm{B}$. and McAleer, M., 2004. Input-output structure and growth in China. Mathematics and Computers in Simulation, 64, pp.193-202. MSSANZ/IMACS 14th Biennial Conference on Modelling and Simulation. doi: http://dx.doi.org/10.1016/s0378-4754(03)00132-0

Kofoworola, O. and Gheewala, S., 2008. An input-output analysis of Thailand's construction sector. Construction Management \& Economics, 26(11), pp.1227-240. doi: http://dx.doi.org/10.1080/01446190802425560

Leontief, W., 1966. Input-output economics. New York: Oxford University Press.

Liu, C. and Song, Y., 2005. Multifactor Productivity Measures of Construction Sectors Using OECD Input-output Database. Journal of Construction Research, 6(2), pp.209-22. doi: http://dx.doi.org/10.1142/S160994510500033X

Pietroforte, R. and Gregori, T., 2003. An input-output analysis of the construction sector in highly developed economies. Construction Management \& Economics, 21(3), pp.319-27. doi: http://dx.doi.org/10.1080/0144619032000056153

Pietroforte, R., Gregori, T. and Falagario, M., 2009. The changing input structure of the US construction industry: a longitudinal analysis. Construction Management \& Economics, 27(11), pp.1089-98. doi: http://dx.doi.org/10.1080/01446190903280443

Raa, T., 2010. Input-output Economics: Theory and Applications. Featuring Asian Economies. Singapore: World Scientific Publishing.

Skolka, J., 1989. Input-output structural decomposition analysis for Austria. Journal of Policy Modeling, 11(1), pp.45-66. doi: http://dx.doi.org/10.1016/0161-8938(89)90024-0

Song, Y. and Liu, C., 2006. The Australian construction linkages in the 1990s. Architectural Science Review, 49(4), pp.408-17. doi: http://dx.doi.org/10.3763/asre.2006.4953

Timmer, M.P., Dietzenbacher, E., Los, B., Stehrer, R. and de Vries, G., 2015. An illustrated user guide to the World Input-Output Database: the case of global automotive production. Review of International Economics, 23(3), pp.575-605. doi: http://dx.doi.org/10.1111/roie.12178

Toh, M. and Thangavelu, S., 2013. An Input-Output Study of the Singapore Information Sector. Economic Systems Research, 25(2), pp.233-44. doi: http://dx.doi.org/10.1080/09535314.2012.740616

Wu, X. and Zhang, Z., 2005. Input-output analysis of the Chinese construction sector. Construction Management \& Economics, 23(9), pp.905-12. doi: http://dx.doi.org/10.1080/01446190500183974 


\section{Appendix 1: WIOD sectoral classifications}

\begin{tabular}{|c|c|}
\hline No & Sector \\
\hline 1 & Agriculture, Hunting, Forestry and Fishing \\
\hline 2 & Mining and Quarrying \\
\hline 3 & Food, Beverages and Tobacco \\
\hline 4 & Textiles and Textile Products \\
\hline 5 & Leather, Leather and Footwear \\
\hline 6 & Wood and Products of Wood and Cork \\
\hline 7 & Pulp, Paper, Paper, Printing and Publishing \\
\hline 8 & Coke, Refined Petroleum and Nuclear Fuel \\
\hline 9 & Chemicals and Chemical Products \\
\hline 10 & Rubber and Plastics \\
\hline 11 & Other Non-Metallic Minerals \\
\hline 12 & Basic Metals and Fabricated Metals \\
\hline 13 & Machinery, Nec \\
\hline 14 & Electrical and Optical Equipment \\
\hline 15 & Transport Equipment \\
\hline 16 & Manufacturing, Nec; Recycling \\
\hline 17 & Electricity, Gas and Water Supply \\
\hline 18 & Construction \\
\hline 19 & Sale, Maintenance and Repair of Motor Vehicles and Motorcycles; Retail Sale of Fuel \\
\hline 20 & Wholesale Trade and Commission Trade, Except of Motor Vehicles and Motorcycles \\
\hline 21 & Retail Trade, Except of Motor Vehicles and Motorcycles; Repair of Household Goods \\
\hline 22 & Hotels and Restaurants \\
\hline 23 & Inland Transport \\
\hline 24 & Water Transport \\
\hline 25 & Air Transport \\
\hline 26 & Other Supporting and Auxiliary Transport Activities; Activities of Travel Agencies \\
\hline 27 & Post and Telecommunications \\
\hline 28 & Financial Intermediation \\
\hline 29 & Real Estate Activities \\
\hline 30 & Renting of M\&Eq and Other Business Activities \\
\hline 31 & Public Admin and Defence; Compulsory Social Security \\
\hline 32 & Education \\
\hline 33 & Health and Social Work \\
\hline 34 & Other Community, Social and Personal Services \\
\hline 35 & Private Households with Employed Persons \\
\hline
\end{tabular}

